\title{
Complete Systematic Land Registration On Communal Land For Investment
}

\author{
Johannes Ibrahim Kosasih and Luh Putu Darmayanti \\ \{info@warmadewa.ac.id\} \\ Universitas Warmadewa Denpasar
}

\begin{abstract}
Complete systematic land registration is one of the efforts made by the government to certify land that can involve an active participation from the community, especially land rights holders to cooperate with the government. This study examines the normalization of conflicts between the regulatory of a Complete Systematic Land Registration with the provisions of the Law on it. This study aims to describe and analyze the regulatory of the Complete Systematic Land Registration program on communal land for investment and the legal consequences of implementing the Communal Land Registration on Investment. The method used in this study is Normative jurisdiction method which specifically examines conflicting legal norms, this study uses the legal basis for the selection of norms, legal certainty and legal protection. Sources of legal materials are divided into primary legal materials, secondary legal materials, tertiary legal materials. The result of this study explained that Systematic Land Registration regulatory of Communal Land for Investment must be based on a hierarchy of legislations which are currently governed by Minister of Agrarian Spatial Planning/Head of National Land Agency Number 9 of 2015, Number 35 of 2016 and Number 12 of 2017 causing conflicts or disharmony. Besides that, the legal consequence of implementing the Communal Land Registration on investment was there is no legal certainty because there has been a conflict of legal norms on the issuance of the Minister of Agrarian Regulation and Spatial Planning/Head of the National Land Agency.
\end{abstract}

Keywords: Systematic Land Registration, Communal, Investment

\section{Introduction}

This study is motivated by the existence of disharmony in the form of conflicting norms between the Minister of Agrarian regulation/Head of the National Land Agency Number 35 of 2016 concerning the implementation Acceleration of Complete Systematic Land Registration with the Law on it, Law Number 5 of 1960 concerning Basic Rules of Agrarian Principles.

Some latest related studies have been conducted with the different aims. One of them was study the development of the law of complete systematic land registration (PTSL) and effect of conduct values of land based on dignify justice in the district of Kendal. The study described that Land Registry Systematic Complete is a land registration activities for the first time conducted simultaneously for all objects of land registration throughout the territory of 
the Republic of Indonesia in the territory of the village/village or other names that level with it, which involves the collection and determination of the truth of physical data and juridical data regarding one or several objects of registration of land for the purposes of registration. Besides that, there are several factors that become obstacles in the implementation of PTSL in Kendal, Central Java [1] The second latest related study examined the complete systematic land registration (PTSL) process in the land office of North Minahasa Regency. The study aims to analyze the implementation and obstacles of Complete Systematic Land Registration (PTSL) at the Land Office of North Minahasa Regency. The results showed that the implementation of a complete systematic land registration at the North Minahasa Regency Land Office was carried out very well. This was shown by the success of PTSL in North Minahasa Regency [2].

However, this present study tried to formulate the problem into (1) how is regulatory of Complete Systematic Land Registration on Communal Land for Investment? (2) What are the legal consequences of implementing the Communal Land Registration on Investment? Thus, based on the research problem above, the aims of this study therefore are to describe and analyze the regulatory of the Complete Systematic Land Registration program on communal land for investment and the legal consequences of implementing the Communal Land Registration on Investment.

\section{Method}

Type of Research used in this study is a type of normative legal research. Problem Approaches used Case approach, statute approach, conceptual approach, Analytical Approach and Philosophical Approach [3]. Sources of legal materials can be divided into 3, they are primary legal materials, secondary legal materials, tertiary legal materials. Legal Material Collection Techniques that are carried out through written legal materials using content analysis, this technique is useful to get a theoretical foundation by examining and studying books, legislation, documents, reports, archives and other research results both print and electronic. Legal material analysis is carried out to solve the problem contained in the formulation of the problem by using qualitative descriptive legal material analysis that is describing a situation or status of phenomena with words or sentences then separated according to categories to obtain conclusions.

\section{Discussion}

\subsection{Implementation of Communal Land Registration for Investment}

Complete Systematic Land Registration regulatory is based on Regulation of Minister of Agrarian / Head of National Land Agency Number 35 of 2016 concerning the implementation acceleration of Systematic Complete Land Registration with reference to the Law on it, Law No. 5 of 1960 concerning Basic Rules of Agrarian Principles. Improved economic growth, abundant natural resources and good economic stability are some of the reasons that made certain parties decide to invest in Indonesia. To understand how much profit is gained by investing in Indonesia, there are some regulatory procedures that must be carried out by those who want to invest. 
The existence of Communal Land in Indonesia is evidenced by the issuance of communal rights certificates to guarantee legal certainty over customary land ownership by custom community is an agrarian reform through progressive legal breakthroughs. However, in its development the existence of communal rights certificates still needs to be revised and adjusted the principles of agrarian reform by taking into account the rules contained in Law Number 5 of 1960 as the main of land rules. Communal rights must be conceptualized as a concept of property rights that are not only public but also private.

In order to obtain communal rights over land, they must meet all the requirements as stipulated in Regulation of Agrarian minister/ Head of the National Land Agency Number 10 of 2016 to be issued a certificate of communal rights then. The issuance of a certificate of communal rights for the achievement of legal certainty for the subject of communal rights law, as the aim to be established the Agrarian minister Regulation / Head of National Land Agency Number 10 of 2016. However, the existence of Minister of Agrarian Regulation / Head of National Land Agency Number 9 of 2015 which was later revoked by Ministerial Regulation Agrarian / Head of National Land Agency Number 10 of 2016, Complete Systematic Land Registration on Communal Land is regulated based on Minister of Agrarian Regulation / Head of National Land Agency Number 35 of 2016 concerning the Implementation Acceleration of Complete Systematic Land Registration, that the three ministerial regulations have equated communal rights with customary rights. Confusing communal rights with customary rights in ministerial regulations is essentially building legal fiction, because customary rights and communal rights have different characteristics, but by ministerial regulations are considered as same. Customary rights have both a public and a civil dimension. The public dimension appears in authority of the customary law community to regulate Land / territory as its living space related to its utilization including its maintenance; Legal relationship between customary law communities and their land; and legal actions related to customary law community land.

\subsection{Legal consequences on implementation of Communal Land for Investment}

Implementation of land registration based on Article 3 of Government Regulation Number 24 of 1997, Issuance of communal rights certificates in the context of agrarian reform is a legal breakthrough by the National Land Agency of Indonesia Republic to carry an overhaul of land ownership and control as well as legal relations relating to land control.

Legal basis for the implementation of Land Control (Land reform) in addition to Article 7, 10 and 17 of the Agrarian Basic Law above, is also regulated in Law No. 1 of 1958 (LN 1958 No. 2) Concerning the Elimination of land of Partikelir jo. Government Regulation No. 18 of 1958 concerning the Law Implementation on the Elimination of Partikelir Land, Law No. 56 government regulations in lieu 1960 (LN 1960 No. 174) concerning Determination of land area of jo Agricultural. Government Regulation No. 224 of 1961 concerning the implementation of land distribution and compensation, Law Number 2 of 1960 (LN 1960 Number 2) concerning Production Sharing Agreements. In carrying out the duties and functions of the land use structuring (Land reform) the activities carried out are Registration of people who have/control land beyond the maximum limit allowed for one family or absentee lands (exposed by Law No. 56), checking the land that has been registered in the list letter a, Determine the parts of the land exposed by the land reform, Execute control of land exposed by land reform and declare that land held directly by the State, Issue work permit to those who are entitled, Register the cultivators and determine the priority order of those who are entitled to get redistribution based on Government Regulation No. 224 of 1961, Redistribute, Regulate and settle compensation to the State and to former owners, Complete certification of lands 
resulting from redistribution and residual land belonging to people exposed by redistribution as a follow up based on Government Regulation No. 10 of 1961 concerning Land Registration, Arranging the production sharing, Arranging pawning settlement based on Law Number 56 government regulations in lieu 1960, Affirming other land reform projects based on the provisions of Government Regulation No. 224 of 1961.

In order to realize the goals of the Indonesian nation and realize a truly political commitment in natural resources management that is just, sustainable, and environmentally friendly as stipulated in the provisions of People's Consultative Assembly of Indonesia Republic Number IX/MPR/2001 concerning Agrarian Reform and Management of natural resources, it is necessary to review the legislations.

A principle of equitable natural resource management, to invest in a sustainable and environmentally friendly that underlies land reform especially on customary lands controlled by custom community, land redistribution here also includes customary land as objects of land reform which must be shared based on the principles of agrarian reform sustainable and environmentally friendly. The principle of agrarian reform was later applied in the land reform program to customary lands through the Regulation of Agrarian Minister/Head of National Land Agency No. 9 of 2015 known as the issuance of communal rights certificates as guarantees of legal certainty given by the State to custom community on communal land to be used as an investment in any field to advance the prosperity of people, especially the communal community.

Communal rights according to Article 1 Paragraph (1) of the Regulation of Agrarian Minister/Head of the National Land Agency Number 9 of 2015 is a common property rights over the land of a customary law community or common property rights over land granted to people who are in a certain area. Communal rights based on this Article contain the conception of common ownership of customary law communities over land. Granting communal rights to customary law community is only in certain areas. Article 1 paragraph (2) Regulation of the Minister of Agrarian / Head of the National Land Agency Number 9 of 2015 concerning procedures for establishing communal rights over customary law community lands and communities within a certain area, in the process of applying for a certificate of communal rights by customary law communities to the Regent and/or mayor, in that application for submission of a certificate of communal rights of custom community must enclose: Profile of customary law communities and their land, if the applicant of a customary law community must enclose profile of land control at least (ten) years or more in a row. If the community applicant is in a certain area must enclosed photocopy of identity card or deed of cooperatives establishment, part units of villages, or other community groups, Certificate from village head. These prerequisites must be met by customary law communities who want to obtain communal rights certificates.

The forms of legal community or legal alliance are identified as social institutions that are public law (publiekrechtelijk) which are the substance of discussion in the customary state administration law (adatstaatsrecht). Because of the public law, the determination of custom community according to experts' doctrine is cumulatively meaning means that custom community must meet these three criteria, a) a permanent group order, b) with their own authority, c) Material wealth is not their own.

The granting of certificates of communal rights on behalf of people of a custom community carries the legal implications of communal land ownership that has become individual ownership. Individual ownership through Article 13 paragraph (3) of the Regulation of the Minister of Agrarian / Head of the National Land Agency Number 9 of 2015 has changed the meaning of communal rights which are considered as ulayat rights that are 
public rights. Through the provision, the legal consequences arising from the regulation of communal rights which turned out to be private are only necessarily eliminating the nature of the existence of ulayat rights as regulated in Law No. 5 of 1960 concerning the basic rules of agrarian law as the main law governing ulayat rights.

Legal consequences of communal land Implementation on Investment, indeed, the legal consequence is a consequence caused by law on an action carried out by a legal subject that can be tangible of born, change or disappearance of a legal condition. For example, legal consequence that can be change, a person from not capable of law to become lawful when he is 21 years old. Legal consequences can be born, change or disappear a legal relationship between two or more legal subjects, where the rights and obligations of one party are dealing with the rights and obligations of other parties. For example, $X$ entered into a rental agreement with $\mathrm{Y}$, accordingly a legal relationship is born between $\mathrm{X}$ and $\mathrm{Y}$ when the rental lease expires, which is marked by the fulfillment of all these rental agreements, then the legal relationship disappears. The sanctions are born when actions are against the law. For example, a thief is given a sanction of punishment is a legal consequence of the act of the thief, that is taking other people's property without rights and against the law.

Based on the description above, the management of Communal Land Rights Certificates must reflect the principles of justice and legal certainty thus it's not cause legal consequences for Communal Land Rights holders to invest on such land therefore it can prevent any conflicts that cause land disputes between Owners or rights holders to Investors.

Along with the era development until now the existence of indigenous territories or wellknown as Ulayat lands is decreasing and almost disappearing. The reduced of the existence of customary law communities' Ulayat land is influenced by a number of factors, one of them is due to the legislations imposed by the Government which were originally issued to protect the rights of custom community, in its implementation inversely to the purpose of issuing these rules turned out to be inversely proportional to the purpose of issuing these rules, thus bringing the impact of the difficulty of custom community in obtaining natural resources from forests for their living needs.

The loss of these rights is sometimes arbitrary so that it will not infrequently result in conflicts between custom law community and right-holders. These fluctuations caused several representatives of the legal community to submit a judicial review or material review of several articles in the Forestry Law No. 41 of 1999.

The articles submitted for the material test are Article 1 number 6, Article 4 paragraph (3), Article 5 paragraph (1) to (3). After several trials, the Constitutional Court Judge stated that the Forestry Law which has been classified as customary forest as state forest is a form of neglect of the rights of customary law communities and violates the constitution therefore, the Customary Forest is excluded from the state forest as part of the forest right.

As a result, at the level of implementation, the existence of Perka BPN No. 9 of 2015 is considered to violate the main rules, UUPA and Government Regulation No. 24 of 1997. The theory used to analyze this discussion is the theory of legal certainty [4]. Legal Protection Theory is used to critically analyze the manufacturing process. Basically, a state that based on law must guarantee equality of each individual, because the rule of law born as an individual struggle to free itself from bounding and arbitrary actions. Furthermore, means of legal protection for people were divided into two: Means of preventive legal protection and Means of repressive protection [5]. The principle of legal protection against government actions rests and comes from the concept of recognition and legal protection of human rights.

\section{Conclusion}


Taking into account the result of this study, thus the conclusion that can be constructed are:

1. Systematic Land Registration regulatory of Communal Land for Investment must be based on a hierarchy of legislations, using the regulation of legal norms, which are currently governed by Minister of Agrarian Spatial Planning / Head of National Land Agency Number 9 of 2015, Number 35 of 2016 and Number 12 of 2017 causing conflicts or disharmony / insynchronization, in which the main purpose of communal land certification through PTSL aims to increase the source of people's economic income in order to realize the ideals of welfare of the nation based on the mandate of Republic of Indonesia constitution and the counterpart in the Law on Land Registration which has function to provide legal certainty for the protection of the rights of Communal communities who uphold the customs and culture of Indonesian people, where land certificates through the PTSL program become a resource that can be used as investment capital to increase the prosperity and welfare of the people as contained in Pancasila and the Opening of the 1945 Constitution of the Republic of Indonesia. The communal land certificate has been implemented through PTSL and is expected to be used for investment later.

2. The existence of Regulation of the Minister of Agrarian Spatial Planning / Head of the National Land Agency Number 9 of 2015, Number 35 of 2016 and Number 12 of 2017 has violated its main rules, Basic Agrarian Law and Government Regulation Number 24 of 1997. Thus, there is no legal certainty because there has been a conflict of legal norms on the issuance of the Minister of Agrarian Regulation and Spatial Planning/Head of the National Land Agency.

\section{References}

[1] D. Hartanti, Gunarto, and A. Purnawan, "Development of the law of complete systematic land registration (PTSL) and Effect of Conduct Values of Land Based on Dignify Justice in the District of Kendal, Central Java," Sultan Agung Notary Law Rev., vol. 1, no. 1, 2019.

[2] B. Iryanto, L. Mandey, and C. Pakasi, "ajian Proses Pelaksanaan Pendaftaran Tanah Sistematis Lengkap (PTSL) di Kantor Pertanahan Kabupaten Minahasa Utara," AGRIRUD, vol. 1, no. 3, 2019.

[3] P. M. Marzuki, Penelitian Hukum. Jakarta: Kencana Prenada Media Group, 2009.

[4] B. Mustafa, Sistem Hukum Administrasi Negara Indonesia. Bandung: PT. Citra Aditya Bakti, 2001.

[5] P. M. Hadjon, Perlindungan Hukum Bagi Rakyat Indonesia. Surabaya: PT. Bina Ilmu, 1987.

[1] D. Hartanti, Gunarto, and A. Purnawan, "Development of the law of complete systematic land registration (PTSL) and Effect of Conduct Values of Land Based on Dignify Justice in the District of Kendal, Central Java," Sultan Agung Notary Law Rev., vol. 1, no. 1, 2019.

[2] B. Iryanto, L. Mandey, and C. Pakasi, "ajian Proses Pelaksanaan Pendaftaran Tanah Sistematis Lengkap (PTSL) di Kantor Pertanahan Kabupaten Minahasa Utara," AGRIRUD, vol. 1, no. 3, 2019.

[3] P. M. Marzuki, Penelitian Hukum. Jakarta: Kencana Prenada Media Group, 2009.

[4] B. Mustafa, Sistem Hukum Administrasi Negara Indonesia. Bandung: PT. Citra Aditya Bakti, 2001.

[5] P. M. Hadjon, Perlindungan Hukum Bagi Rakyat Indonesia. Surabaya: PT. Bina Ilmu, 1987. 